\title{
AKIL VE İMAN: MESELEYE KELÂMÎ NAZAR*
}

\author{
Cağfer KARADAŞ \\ Prof. Dr., UÜ. İlahiyat Fakültesi \\ caferkaradas@hotmail.com
}

Öz

Makalede, dinin muhatabı akıllı insan olması hasebiyle aklın kelamî açıdan manası, mahiyeti, insan vücudundaki yeri, işlevi, değeri, akıl-duyu ve akıl-haber ilişkisi ile aklın gaybı bilmesi imkânı üzerinde duruldu. Üç temel kelam mezhebi olan Mu'tezile, Matüridiyye ve Eş'ariyye'nin akılla ilgili görüşleri, birleştikleri ve ayrıştıkları noktalara dikkat çekildi. Makalenin temel konusu olan iman ve akıl arasındaki irtibatın nasıl olduğu hususuna yer verildi. Akılla nassın yerlerinin uygun bir şekilde belirlenmesi ve ikisinin birlikte ele alınması hususuna getirilen değerlendirmeler irdelendi. Öte yandan nassa bağlllı̆̆ı ile bilinen Ehl-i Hadîs mezheplerinden Hanbelî mezhebi içinde bile metinlerin zahirine aşırı vurgulun neticede tecsim ve teşbihe yol açtığına içerden tespitlere işaret edildi. İster Ehl-i Hadîs ister Sufiye olsun akıldan mutlak kopuk ve bağımsız olunamayacağı gerçeği kelam âlimlerinin bu alandaki haklılığının tespitidir.

Anahtar Kelimler: Akıl; İman; Kelâm; Mu’tezile; Matüridiyye; Eş’ariyye; Ehl-i Hadis.

\section{REASON AND FAITH: AN APPROACH TO THE PROBLEM FROM THE VIEWPOINT OF KALĀM}

\begin{abstract}
This article addresses some questions regarding the reason which makes the human to be object of religious responsibility, in terms of its meaning, essence, place, role, value and function in human body as well as relationships between reason-sensation and reason-report in the context of kalâm. The views of three main kalâm schools about the reason and their agreement or disagreement on this issue are also pointed out. The question of the connection between reason and faith is established as a main topic of the article. Assessments of the convenient determination of the place of reason and revelation and the mutual evaluation of the two are examined. Additionally, it is pointed out that the Hanbali sect gives rise to tajseem and tashbeeh, anthropomorphic approaches to God. Both in terms of Ahl al-Hadith and Sufis, the fact that reason is indispensable for these issues proved that mutakallimūn were right in this regard.
\end{abstract}

Keywords: Reason; Faith; Islamic Theology; Mu'tazila; Maturidis; Ash'arites; Ahl al-Hadith.

Bu makele, Din Felsefesi Derneği'nin Sakarya Üniversitesi İlahiyat Fakültesinde 02-03 Mayıs 2015 tarihinde düzenlediği "Akıl-İman İlişkişi” konulu Atölye Çalışmasında sunulan "Akıl ve İman -Kelam İlmi Nokta-i Nazardan Değerlendirme-" başlıklı bildirinin genişletilmiş, gözden geçirilmiş ve makale formatına sokulmuş şeklidir. 


\section{Aklın Mana ve Mahiyeti}

İslam düşüncesinde akıl, genellikle bir temyiz/tefrik gücü olarak görülmüş, bu güç de hüsn-kubuh/iyi-kötü arasını ayırt edebilme kabiliyeti/sıfatı veya hissi/cihazı olarak tanımlanmıştır.

Kur'an-1 Kerim'de, akıl etmedikleri/akıllarını kullanmadıkları için insanların kınanmaları, sanki insanda bilgi elde etmeye hazır bir tarafın bulunduğu ve bunun kullanılmaması dolayısıyla anılan kınamayı hak ettiği şeklinde yorumlanmış; aklı olmayana itikadî ve amelî bir teklifin yapılmaması ise, insanda akıl gücünün varlığına işaret sayılmıştır. Zira Allah, teklifi akla bağlamış ve vacip olan ile olmayan arasını ayırabilsin diye akıl bir imkân olarak ona verilmiş, bu yüzden Allah'ı bilmemesi bir mazeret kabul edilmemiştir. ${ }^{1}$

Mu'tezile'den Ebü'l-Huzeyl el-Allaf aklı duyu olarak tanımlar ve insanın ergenlik çağına ulaşmasının (buluğ) aklın kemali ile mümkün olacağı kanaatini ortaya koyar. Ona göre akıl zorunlu bilgileri taşıyan ve iktisabî bilgileri elde eden bir kuvvettir. Öte yandan aklı ilim olarak tarif eden Mu'tezile'den Muhammed b. Abdulvehhab el-Cübbaî, gerekçesini aklı olmayanın kendisini koruyamadığı hususlardan, akıl sahibinin kendisini koruması şeklinde dile getirir. Öyle görünüyor ki Mu'tezile kelamcılarının çoğu aklı buluğa ermiş olmanın bir gereği ve gerekçesi olarak görmektedirler. Öte yandan akıl ve kalbin birbiri yerine kullanıldığ 1 vakidir. Buna en güzel örnek Kadî Abdulcebbâr'dır. Ona göre tefekkür, tedebbür ve teemmülü içine alan nazar (düşünme) kalp ile gerçekleşir. Bu tür nazar günlük işler ve ticarî faaliyetlerde kullanılabileceği gibi inanca dair şüpheleri gidermek ve marifetullaha ulaşmak gibi ulvî alanda da istihdam edilebilir. ${ }^{2}$

Akıl hakkında ilk eser verenlerden Hâris el-Muhasibî, aklı Allah'ın insan bünyesine koyduğu bir garize olarak niteler ve bunun da ancak insan fiilleri ile bilinebileceğine dikkat çeker. Çünkü akıl, görme, işitme ve tatma gibi duyu yoluyla kavranamaz ancak, insanların fiillerine bakılarak kişinin akıllı veya akıldan yoksun olduğu anlaşılabilir. Burada Muhasibî, Kur'an'da aklın fiil kalıbında geçmesini dikkate almaktadır. Ona göre fiillerin arkasında mutlaka iyiyi ve kötüyü ayırt edebilecek bir akıl vardır. Nitekim günlük hayatta da insanlar, görünüşlerinden veya kalıplarından daha çok fiilleri ile değerlendirilir. Eğer iyi ve kötüyü ayırt edebilen bir şahıs ise, ona toplum akıllı, değilse deli veya ahmak ismini verir. Kendi döneminde bazı kelamcıların öz anlamına gelen lüb kavramından hareketle akıl için ruhun özü demelerini doğru bulmaz ve gerekçe olarak da buna dair bir nassın kendilerine gelmediğini ileri sürer. Aynı şekilde akıl için marifet denmesini

Cessas, Ahkâmü'l-Kur'ân, Beyrut 1424/2003, Daru'l-Kütübi'l-İlmiyye, I, 33; Ebü'l-Münteha, el-Külliyât, Beyrut 1412/1992, Müessesetü'r-Risâle, s. 618.

2 Ebü'l-Hasan el-Eş'arî, Makâlâtü'l-İslamiyyîn, nşr. H. Ritter, Wiezbaden 1980, s. 480-482; Kadî Abdulcebbar, Şerhu'l-usûli'l-hamse, Kahire 1364/1965, Mektebetü Vehbe, s. 45.

\begin{tabular}{|c|c|c|}
\hline Alâm Araștırmaları & $\begin{array}{l}\text { Kelâm Araştırmaları Dergisi } \\
\text { Journal of Kalâm Researches } \\
\text { [KADER-e-ISSN: 1309-2030] }\end{array}$ & $\begin{array}{cc}\text { C.: } 13, & \text { S.: } 2 \\
\text { V.: } 13, & \text { I.: } 2 \\
2015\end{array}$ \\
\hline
\end{tabular}


reddeder. Ona göre akıl ahmaklığın ve deliliğin zıddıdır; doğum ile birlikte yaratılan bu garize, insanın gelişmesine paralel gelişir; kalp ve organlar üzerindeki fiili tesiri ile ancak bilinebilir/ölçülebilir. ${ }^{3}$

Kelam düşüncesi içerisinde aklın tarifi hususunda dört temel görüş bulunmaktadır. Mu'tezile aklı, araz kabul ederken Ehl-i Sünnet kelamcilarının çoğu aklı, ruh gibi ayan yani cevher ve cisim türünden sayar. Şafi ve ilk sünnî kelamcılardan Kalanisî aklı temyiz gücü veya aleti şeklinde tarif ederler. İmam Eş'arî, aklı ilmin özel bir hali olarak görür ve umumhusus dışında ilim ile akıl arasında aslında bir fark olmadığını dile getirir. Ancak Eş'ariler içinde aklın mahiyeti konusunda oldukça farklı anlayışların olduğu da bir gerçektir. Sözgelimi mezhebin önde gelenlerinden Bakıllanî aklı, vacip ve caiz olanı zaruri olarak bilmek şeklinde tanımlarken Cüveynî el-İrşad adlı eserinde bu görüşe destekler ancak, el-Bürhan adlı usûl kitabında ilimlerin kendisiyle idrak edildiği sıfat olduğu şeklinde bir açıklama getirir. Aklı Muhasibî'de olduğu gibi bir garize ve güç olarak gören Gazzalî aklın dört anlamının olduğuna dikkat çeker ve şöylece sıralar: a. İnsanı diğer hayvanlardan ayıran bir vasıf veya garize, $b$. Mümeyyiz olan çocukta ortaya çıkan zorunlu bilgiler, c. Tecrübelerden elde edilen bilgiler, d. İşlerin sonucunun neye varacağını bilme gücüne erişen bir garize. Ona göre aslında bilgiler insandaki bu garizede yaratılıştan (fitreten) imkan olarak bulunmakta olup sebeplere bağlı olarak gün yüzüne çıkarlar. ${ }^{4}$

Matüridî kesimden Ebü'l-Yüsr el-Bezdevî gözün görme, kulağın duyma, burnun koklama yoluyla bilgi edinme araçları olması gibi akıl da bir bilgi edinme aracıdır. Mahiyet itibariyle akıl aydınlatıcı latîf bir cisimdir. Aklın kalp ile ilişkisi ise, eserinin kalp üzerinde gerçekleşmesi şeklindedir. Bu eser ile kalp aklın nuru ile gerçek anlamda bir müdrik yani algı mekanizmasının tepe noktasını oluşturur. Aklın buradaki fonksiyonu, Güneşin ışığı ile gözün görmesini sağlaması gibidir. ${ }^{5}$

Felsefeciler ise aklı, nefis gibi, ulvî âlemin bir parçası olarak görmüşler, oradan bedene intikal ettiğini, bedenin düzeninin/itidaliyetinin bozulması ile yeniden aslî âlemine döneceğini iddia etmişlerdir. Bazı felsefeciler aklı, nefs-i natıka olarak görmüş ve üst varlıklara tesir etmesi ve bizzat nefs-i natıkadan istifade ederek cevherini ikmal etmesi dolayısıyla akla, nazarî akıl; nazarî akıldan yardım alarak içinde bulunduğu bedene tesiri itibariyle de amelî akıl demişlerdir. Zaten felsefeciler aklı çok geniş anlamda kullanmışlardır. Nitekim kelamcıların aksine "Tanrı âkil, ma'kul ve akıldır" demek suretiyle aklı Allah için de kullanmanın yanında tanrıdan sudur ettiğine inandıkları ilk varlıkların da akıllar olduğunu, hatta cismani

Hâris el-Muhasibî, Şerefü'l-akıl ve mahiyyetüh û, Beyrut 1406/1986, Daru'l-Kütübi'l-i̇lmiyye, s. 17-19.

4 Gazzalî, "Fi'l-Akli ve Şerefuhû", Hâris el-Muhasibî, Şerefü'l-akıl ve mahiyyetüĥu, Beyrut 1406/1986, Daru'l-Kütübi'l-İlmiyye ile birlikte, s. 57-62.

5 Ebü'l-Yüsr el-Bezdevî, Usulü'd-dîn, nşr. H.P. Linss, Kahire 1383/1963, s. 205-206.

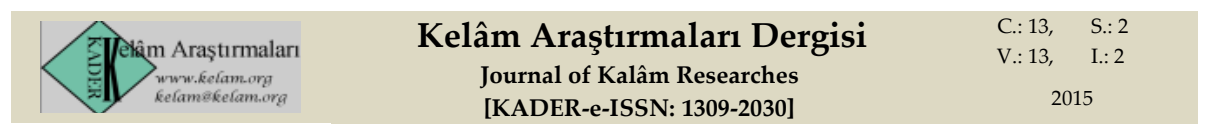


alemdeki suret ve heyulanın birleştirilmesi ile oluşu, ayrıştırılması ile bozuluşu meydana getirenin akl-1 faal olduğunu ileri sürmüş̧lerdir. ${ }^{6}$

Tarihi tecrübe dikkate alındığında akılların aynı düzeyde yaratılmadığı/var olmadığı bir gerçektir. Kiminin aklı daha yeterli iken göreceli olarak bazı kimselerin aklı daha az yeterlidir. Nitekim peygamberin aklı ile normal bir insanın aklının aynı olmadığı müsellemdir. Nitekim Hz. Peygamber'in aklî yönden tam olduğu hususunda hem inananlar hem de inkârcılar birleşmiştir. $\mathrm{O}$, aklın kemali bakımından tam, ahlakî yönden en mükemmel, görüş açısından da en üstündür. Bazıları İbn Sina'nın aklının diğer insanların aklına göre fevkalade üstün olduğunu söylemişlerdir.7 Zeydiyye'den Nâsıruddîn Ahmed, Yüce Allah'ın adaleti gereği akılları aynı düzeyde yarattığını ancak daha sonra insanın çaba ve çalışmasına göre akılların artma ve eksilmeye uğradığını dile getirir. Başka bir deyişle akıllardaki farklılık yaratılış itibariyle veya tabiat itibariyle değil, çalışma ve gayret (iktisabî) iledir. ${ }^{8}$

Mahiyeti konusunu tartışanlar, aklın bir taalluk/fonksiyon veya cevher ve araz türündün bir gerçeklik olup-olmadığı hususunda farklı görüşler ileri sürmüşlerdir. Kelamcılardan aklın ilim ile aynı olduğunu düşünenler, onun kalbin bir fonksiyonu olduğunu ileri sürerken aklı maddî/tabiî bir gerçeklik olduğunu kabul edenler ise, bunun ya ruh, nefis, kalp ve beyin gibi bir organ ya da sıfat/araz olduğunu dile getirmişlerdir. Öte yandan mahiyet itibariyle aklı, nefsi ve zihni aynı şey sayanlar, bunların ayrı ayrı telakki edilmesinin nefsin tasarruf sahibi olması, zihnin idrake hazır bulunması, aklın ise bizzat idrak eden konumunda olması dolayısıyla düşünülmüş olabileceğine dikkat çekmişlerdir.

Aklın kadîm olup olmaması meselesinde kelam, fıkıh ve hadis âlimleri aklın bir gerçeklik olduğunu ancak kadîm olmadığını ileri sürmüşlerdir. Zaten başta kelamcılar olmak üzere Kur'an ve sünneti dinin temel dayanağ kabul eden alimlere göre Allah dışında kadîm varlık söz konusu değildir. Buna karşıllk aklın kadîm olduğu kanaatinde olan felsefeciler, mahiyeti konusunda ikiye ayrılmışlardır. Bir kısmı aklı latif cevher kabul ederken diğerleri bileşik olmayan basit cevher olduğunu ileri sürmüşlerdir. ${ }^{9}$

\section{Aklın İnsan Vücudundaki Yeri}

İslam düşüncesinde aklın insan vücudundaki yeri olarak kalp veya beyin gösterilmiştir. Kelamcılar ile Şafîi aklın yerinin kalp olduğunu görüşünü benimserken felsefeciler, tabipler ve Ebû Hanife aklın yerinin beyin olması görüşünü tercih etmişlerdir. Aklın yerinin kalp veya beyin olduğu

Ebü'l-Münteha, el-Külliyât, s. 619.

Cessas, Ahkâmü'l-Kur'ân, , I, 33; Ebü'l-Münteha, el-Külliyât, s. 619.

Nâsıruddîn Ahmed, en-Necât, nşr. Seyyid Abdullah, Kahire 14021/2001, s. 59-60.

Kurtubî, el-Cami' li ahkâmi'l-Kur'ân, Kahire 1426/2005, Daru'l-Hadîs, I, 239-240; Ebü'1-

Münteha, el-Külliyât, Beyrut 1412/1992, s. 617-620.

\begin{tabular}{|c|c|c|}
\hline Siĝm Arasttırmaları & $\begin{array}{l}\text { Kelâm Araştırmalari Dergisi } \\
\text { Journal of Kalâm Researches } \\
\text { [KADER-e-ISSN: 1309-2030] }\end{array}$ & $\begin{array}{cc}\text { C.: } 13, \quad \text { S.: } 2 \\
\text { V.: } 13, \quad \text { I.: } 2 \\
2015\end{array}$ \\
\hline
\end{tabular}


hususunda felsefeciler de ihtilaf etmişlerdir. Bir üçüncü görüş olarak hem kalbin hem beynin aklın mekanı olduğu görüşünü ileri sürenler de olmuştur. Bu üçüncü görüşe göre bilginin insanda idrak düzeyine ulaşması şöyle gerçekleşmektedir: Ruhanî manalar önce ruha, oradan kalbe intikal eder, oradan beyne yükselir, son olarak da mütahayyileye işlenir (naşk) ve böylece idrak süreci tamamlanmış olur. Hz. Ali'ye nispet edilen "Akıl kalptedir, rahmet ciğerdedir, şefkat dalaktadır, nefes akciğerdedir" sözü, aklın yerinin kalp olduğunu ifade etmektedir. ${ }^{10}$

Ebû Mansûr el-Matüridî, kalbin akıl yerine kullanıldığı kanaatindedir. Zaten aklın insan vücudundaki yeri konusunda da ihtilafa vardır. Nitekim bir kısım insanlar kalp aklın mahallidir derken diğer bazıları aklın yeri kafadır ancak nuru kalbe ulaşır görüşünde olmuşlardır. Bu durumda kalp ancak akıl vasıtasıyla gaybî haberlere muttali olabilmektedir. Zira aralarında bir komşuluk ilişkisi sözkonusudur. Bu yüzden de akıl, kalp diye adlandırılmış olsa gerektir. ${ }^{11}$ Semerkant ulemasından Ebü'l-Yüsr el-Bezdevî'ye göre aklın yeri, baş yani beyindir, bunun böyle kabul edilmesi insanın kafasına ağır bir nesne ile vurulduğunda aklını yitirmesinden anlaşılır. Osmanlı ulemasından Beyazîzade aklın yerinin yani başlangıç noktasının Ehl-i Sünnetin çoğunluğuna göre kafa/beyin olduğunu söylerken aklı bir kuvve/nur olarak gören Ebü'l-Usr Fahru'l-İslam el-Bezdevî ve Ebü'l-Muîn en-Nesefi aklın herhangi bir yerinin olmadığını ifade etmişlerdir. ${ }^{12}$

Eş'arîlerden Fahreddîn er-Razî kitap, sünnet ve aklî delillerden yola çıkarak aklın yerinin kalp olduğu hususunda kesin ifadeler ortaya koyar. Ona göre akıl kalptedir, işitme ve görme gibi duyular ise ona götüren bir yoldur. Çünkü kalp, hüküm veren ve aynı zamanda hükmedendir. Görme ve duyma kalbin diş dünyaya açılan pencereleridir. Beynin fonksiyonunu dışlamayan Razî, beyni kalbin yakın aleti, duyuları ise uzak aleti olarak tanımlar. O buradan hareketle alg1/kavrama hiyerarşisini "duyular beyne, beyin de akla hizmet eder" diyerek algının duyulardan başlayıp beyin yoluyla kalpde son bulduğunu ve böylece algı işleminin tamamlandığını ileri sürer. Ayrıca Razî, Kur'an'da kalp yerine kullanılan 'fuâd'ın kalbin müradifi bir kavram değil, kalbi içine alan geniş anlamda idrak merkezi olduğunu iddia eder. ${ }^{13}$ Eş'arîlere yakın sufîlerden Ebü'n-Necîb esSuhreverdî ise, akıl, kalpte basîret ve kuvvettir. Kalbe göre konumu,

10 Ebü'l-Münteha, el-Külliyât, s. 619.

11 Matüridî, Te'vilâtü Ehli's-Sunne, nşr. Fatıma Yusuf el-Haymî, Beyrut, Müessesetü'l-Risâle, IV, 569.

12 Ebü'l-Yüsr el-Bezdevî, Usulü'd-dîn, s. 206-207; Beyazîzâde Ahmed, İ̧ârâtü̈l-merâm, Kahire 1368/1949, s. 77-78.

13 Fahreddîn er-Razî, et-Tefsîru'l-Kebîr (Mefâtîhu'l-gayb), Beyrut, Daru İhyau't-Turasi'l-Arabî, XXIV, 166-168.

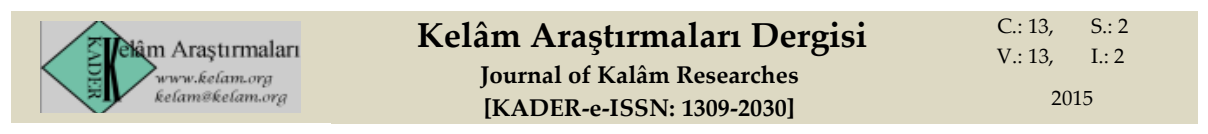


görmenin göze göre konumu gibidir. Yani kalbin akletmesi gözün görmesi gibidir. ${ }^{14}$

\section{Aklın İşlevi ve Değeri}

Aklı bir garize olarak gören Haris el-Muhasibî, aklın vazifesini yerine getirebilmesi için peygamberin rehberliği ve talimine ihtiyaç duyduğunu ileri sürer. Ona göre $\mathrm{Hz}$. Adem örneğinde görüldüğü gibi akıl sahibi, isimleri ancak talim ile öğrenebilmiştir. Akıl, her ne kadar Allah'ın nimet olarak bahşettiği bir hüccet ise de, teklifin gerçekleşmesi, uyarıcı bir peygamber gönderilmesine ve kitap indirilmesine bağlıdır. Akıl fonksiyon itibariyle fehim ve basiret olarak ikiye ayrilır. Fehim burada beyan anlamındadır ve bu tür akıl mümin kafir herkese şamildir. Ancak aklın basiret boyutu iyi ile kötüyü, zararlı ile faydalıyı, necata ermek ile azaba duçar olmayı ayırt edebilecek özelliktedir. Bu ancak mümin kullarda bulunur. Bu durumda fehim ve basiret aklın iki fonksiyonu mesabesindedir. “Ölen/azaba düçar olan bir gerekçe (beyyine) ile yaşayan/necat eren bir gerekçe ile yaşasın diye. Çünkü Allah işiten ve bilendir."15 Zaten akıl imtihan edilmek üzere yaratılmış olan insanın emir ve nehiylere muhatap olmasının bir gerekçesi olsun diye insanın bünyesine yerleştirilmiştir. Bu yönüyle akıl, teklifin/dinî sorumluluğun dayanağıdır. Nitekim kelam ilminde asıl olan Kitap ve Sünnettir. Buna göre kesin bilgi de Kitap, sünnet ve icmaadan elde edilen bilgidir. Makul olanın buna aykırı düşmesi de söz konusu değildir. Çünkü akıllarımız hakikat noktasında sınırlı bir imkana sahiptir ve bu yüzden bir yol göstericiye ihtiyacı bulunmaktadır. ${ }^{16}$

Ebû Mansûr el-Matüridî, aklın şeylerin sebepleri ve delillerini bilebileceğini hakikatini ve künhünü bilmesinin ise söz konusu olmadığını dile getirir. Örneğin bir şehirden diğer şehre giden yolu akıl bilebilir ancak yolun nasıl ve ne gibi imkân ve ihtimalleri barındırdığını bilemez. İlim ise olgu ve olayların hakikatine, künhüne ve tasavvuruna ulaştırır. Bu yüzdendir ki Yüce Allah "Biz bu misalleri insanlar için getirdik. Bu misalleri ancak alimler akılları ile kavrayabilirler."17 $\mathrm{Bu}$ ayette ilmin akla öncelenmesi, aklın sebepleri bilmesi, ilmin ise hakikatlere ulaştırması dolayısıyladır. Çünkü Matüridî akıl her ne kadar şeylerin iyi veya kötü olduğunu kavrasa bile bunların hakikatine ulaşmanın ancak sem'î bilgi ile olabileceğini kabul eder. ${ }^{18}$ Ebü'l-Yüsr el-Bezdevî'nin nakletiğine göre Matüridî, gerçek vacip kılanın Allah olduğu ancak, bunun için aklı sebep kıldığı görüşündedir. Buna göre akıl vacip kılmanın bir illeti veya sebebidir. Başka bir deyişle nasıl

14 Ebü'n-Necîb es-Suhreverdî, Âdâbü'l-mürîdin, nşr. Nuceym Muhammed Şeltut, Kahire ts., Daru'l-Vatani'l-Arabî, s. 51.

15 el-Enfâl 8/42.

16 Hâris el-Muhasibî, Şerefü'l-akıl ve mahiyyetüh $\hat{u}$, s. 19-24; Sadüddîn et-Teftazânî, Şerhu'lMekâsıd, Beyrut 1409/1989, Alemü'l-Kütüb, I, 177; Cürcânî, Şerhu'l-Mevâkıf, Kahire 1325/1907, el-Hac Muhammed Efendi, I, 248.

17 el-Ankebut, /43

18 Matüridî, Te'vilâtü Ehli's-Sunne, IV, 20, 569.

\begin{tabular}{|c|c|c|}
\hline Siâm Araştırmaları & $\begin{array}{l}\text { Kelâm Araştırmaları Dergisi } \\
\text { Journal of Kalâm Researches } \\
\text { [KADER-e-ISSN: 1309-2030] }\end{array}$ & $\begin{array}{cc}\text { C.: } 13, & \text { S.: } 2 \\
\text { V.: } 13, \quad \text { I.: } 2 \\
2015\end{array}$ \\
\hline
\end{tabular}


ki gerçekte tek yaratıcı Allah ise, yegâne vacip kılan da ancak O'dur. Ancak şeriat insanların hükümleri kolayca anlaması için bazı sebepler/illetler koymuştur. Bir olgu veya olay hakkında vacip hükmüne yol açan sebeplerin de aklî değil, şer'î olması gerekir. ${ }^{19}$

Matüridîlerden Ebü'l-Usr Fahru'l-İslam el-Bezdevî́ye göre akıl, duyuların kavramasının son noktasında devreye giren bir nurdur. Akıl ilim değildir, vacibi idrak ve bilgi elde etmek bir vasitadır; duyular ise aklın sadece araçlarıdır. Ebü'l-Münteha'nın naklettiği şu görüş bununla örtüşmektedir: Akıl, insanın içinde bir nurdur ve bu nur sayesinde kalp yani insan nefsi duyuların ulaşamadığı alanlara dair teemmül ve tefekkür ile bilgi sahibi olur. Bu yüzdendir ki "duyuların fonksiyonlarının bittiği yerde akıl devreye girer" (بداية العقول نهاية المحسوسات ). Buna göre akıl, duyular ötesi evren veya varlıklar için bilgi edinme fonksiyonunu yerine getirir. Ebû Yüser el-Bezdevi ise aklın görevinin idrak mekanizmasının tepe noktasını temsil eden kalbe yardımcı olmak olduğunu söyler. Bunun anlamı, aklın eserinin kalpte ortaya çıkması ve oradan dış dünyaya yansımasıdır. Diğer bir deyişle kalp akıl nuru ile olgu ve olayları idrak eder. ${ }^{20}$

Mutezile kelamcılarına göre akıl muarrif yani eşyayı tanımlayan ve mucib yani eşya hakkında vacip hükmü koyandır. Buna göre akıl, dinde hüküm koyma fonksiyonuna sahiptir. Ancak Mu'tezile vacip hükümleri aklî ve şer'î olmak üzere ikiye ayırır. Aklî kısmına dâhil olanlar emaneti iade etmek, borcu ödemek ve nimete şükretme gibi mükelleften hiçbir hal ve şartta sakıt olmayan hükümlerdir. Şer'î kısımda bulunanlar ise, Allah'a yakın olmak ve ibadet etmek gibi hükümlerdir. Ancak söz konusu şer'î hükümlerin vacipliği marifetullahın akabinde ve ona bağlı olarak gerçekleşir. ${ }^{21}$

Ehl-i Sünnet'ten Eş'arilere göre akıl, ne muarrif ne de mucibdir, dolayısıyla tanımlama ve hüküm koyna yetkisi de bulunmamaktadır. Cüveynî, aklın öngördüğü şekilde Allah'ın hüküm koymasının kabul edilemez olduğunu vurguladıktan sonra şu kesin yargısını dile getirir: Şayet şeriat ortadan kalksa ve başvurulabilecek kişi veya eser kalmasa insanlar sanki kendilerine hiç şeriat gelmemiş gibi kabul edilirler, yani teklif ortadan kalkar. Gazzâlî ise, imanî noktadan başlayarak şayet şeriat gelmeseydi, kullara Allah'ı tanımak (marifetullah) vacip olmazdı der. Ona göre akıl her ne kadar fayda ve zararı bilir ve sahibini bunlara teşvik ederse de, faydalı gördüğünün sevabı, zararlı addettiğinin cezayı gerektireceğini bilmesi söz konusu değildir. Bunlar ancak şeriatla sabit olur. Zaten vucubiyet ancak tercih edicinin tercihine göre şekillenir, burada tercih eden de akıl değil, Yüce Allah'tır, dolayısıyla vacip kılmak ancak şeriatla söz konusu olmaktadır.

19 Ebü'l-Yüsr el-Bezdevî, Usulü'd-dîn, s. 207-208; Ebü'l-Berekât en-Nesefî, Şerhu Hafizüddîn en-Nesefi li Kitabi'l-Müntehab, nşr. Salim Ögüut, İstanbul ts., s. 547.

20 Ebü'l-Yüsr el-Bezdevî, Usûlü'd-dîn, s. 206-207; Beyazîzâde Ahmed, İ̧ârâtü̈l-merâm, s. 77; Ebü'l-Münteha, el-Külliyât, s. 618.

$21 \quad$ Kadî Abdulcebbar, Șerh, s. 70.

\begin{tabular}{|ccc} 
Kelâm Araştırmaları Dergisi & C.: $13, \quad$ S.: 2 \\
Journal of Kalâm Researches & V.: $13, \quad$ I.: 2 \\
[KADER-e-ISSN: 1309-2030] & 2015
\end{tabular}


Sözgelimi peygamber temsilî olarak sanki şöyle demektedir: "Küfür helak edici bir zehir, iman ise mutluluğa götüren bir şifadır. Bunları böyle tanımlayan Yüce Allah'tır, yoksa benim herhangi bir şeyi size vacip kılmam söz konusu değildir. Ben sadece bir haber veren ve yol gösterenim. Benim doğru söylediğimi mucizeye bakarak anlayabilirsiniz. Eğer benim gösterdiğim yola girerseniz, kurtuluşa erersiniz; girmezseniz, helak olursunuz." Bu temsilden de anlaşılıyor ki, Gazzalî aklı bir tercih edici, hüküm koyucu değil, yol gösteren, haber veren ve kurtuluş (necat) için doğruya yönelen olarak görmektedir. ${ }^{22}$

Ebü'l-Hasan el-Eş'arî akılla bilgi elde etmek ile bu bilginin kişiye vacip olmasının ayrı düşünülmesi gerektiğini belirtmiş ve akıl birçok hususu bilebilir ama bu bilgilerin gereğinin yapılmasının kişiye vacip olması ancak şeriatladır görüşünü dile getirir. Eş'arîlerden Ebû Bekir İbnü'l-Arabî, Kur'an ve Sünnetin dinî alandaki bilinmesi gereken her şeyi açıkladığını, bunları aklın bilmesinin ve kavramasının imkân dâhilinde olmadığını, akla düşen görevin yaratıldığı istidat üzere bütün bu hakikatleri ve açıklamaları kavramak olduğunu dile getirir. Dolayısıyla aklın görev alanının naslarda açıklanan makulleri kavramak olduğu açıtır. Zaten bu hakikatleri aklın anlaması da ancak eğitim yoluyla olacaktır. Bu yüzdendir ki, Yüce Allah seçtiği bir takım insanlarla bu talim ve terbiye işinin gerçekleşmesini sağlamıştır. Çünkü insanın ömrünün kısa ve donanımlarının sınırlı olması, dünya hayatında bütün hakikatleri kavramasına imkân tanımaz. ${ }^{23}$

Hanefilere/Matüridilere göre her ne kadar Yüce Allah peygamber göndermese dahi akıl sahibinin Allah'a inanması ve nimete şükrü iyi, nankörlügü ise kötü görmesi üzerine vacip olmakla birlikte son noktada akıl aciz bir alettir, gerçekte tanım ve hüküm koyma (muarrif ve mûcib) yetkisi sadece Yüce Allah'tadır. Ancak Allah bu hüküm koyma işini peygamberler vasıtasıyla yerine getirir. Çünkü peygamberlerin akılları kemal bakımından tamdır ve bu görevi hakkıyla yerine getirirler. Ancak onların görev alanları da Allah'ın kendilerine bildirdiğini muhataplarına iletmeleri ile sınırlıdır. Özellikle gaybî konularda Yüce Allah peygamber dişında kimseye bilgi vermediğini Kur'an'da bildirmektedir. ${ }^{24}$ Böylesi bir özellik aynı zamanda

22 Cüeynî, el-Giyâsî -Giyâsü'l-ümem fi'ltiyâsi'z-zulem-, nşr. Abdulhalim Dîb, Kahire 1401, Matbaatü Nahda, s. 526; Gazzalî, el-íktisâd fi'l-i'tikâd, nşr. İ.A. Çubukçu-H. Atay, Ankara 1964, AÜİF. Yayınları, s. 189-193.

23 Şehristanî, Nihâyetü'l-İkdâm, Beyrut 1425/2004, Dâru'l-Kütübi'l-İlmiyye, s. 209; Ebû Bekir İbnü'l-Arabî, Kanûnü't-te'vîl, nşr. Muhammed Süleyman, Beyrut 1990, Daru'l-Garbi'lİslamî, s. 180-182; Teftazânî, Şerhu'l-Akâid, nşr. Muhammed Adnan Derviş, yy. ts., s. 206207.

24 “Allah, olduğunuz hal üzere sizi başıboş bırakacak değildir. İyi ile kötüyü, inanan ile inanmayanı birbirinden ayırt edecektir. Allah, gaybın bilgisini de size verecek değildir. Sadece peygamberlerinden dilediklerini seçer ve bu bilgiyi onlara verir. Allah'a ve elçisine inanın. Eğer inanır ve sakınırsanız sizin için büyük bir mükâfat vardır." (Âl-i İmrân 3/179).

\begin{tabular}{|ccc} 
Kelâm Araştırmaları Dergisi & C.: $13, \quad$ S.: 2 \\
Journal of Kalâm Researches & V.: $13, \quad$ I.: 2 \\
[KADER-e-ISSN: 1309-2030] & 2015
\end{tabular}


onların peygamberliklerinin bir işareti ve aklın fonksiyonunun ve sınırlarının ne kadar olduğunun da bir göstergesidir. ${ }^{25}$

Ebü'l-Münteha üç mezhebin görüşünün tam olarak açıklığa kavuşması için şöyle bir örnek getirir: Henüz baliğ olmamış ama akıl sahibi yani temyiz gücüne ulaşmış bir çocuk, Mu'tezile'ye göre iman-küfür şeklinde hiçbir inancı olmasa dahi sorumludur, Eş'arilere göre böyle bir çocuğun hiçbir sorumluluğu yoktur, Matüridilere göre ise eğer şirk yönünde tercih belirtmemişse mazurdur, şirke düşmüşse mazur değildir. ${ }^{26}$

İyi ve kötü konusuna gelince, iman ve küfür gibi bir kısmının akılla bilinmesi mümkün iken namazın farz ve hür adamın köleleştirilmesinin haramlığı gibi ancak şeriatle bilinir. Hem akıl ve hem şeriatın ortak olduğu hususlar da söz konusudur. Bu noktadan hareketle bazı Hanefi fakihleri iyi ve kötünün (hüsün ve kubh) aklen bilinebileceğinden hareketle haram ve helaller konusunda aklın yetkili olduğu görüşüne kani olmuşlardır. Onlara göre hakkında şer'i delil bulunmadıkça ve akıl tarafından mahzurlu sayılmadıkça her şey mubahtır. Çünkü iyi olanın (hüsn) emredilmesi, emreden Yüce Allah'ın hikmeti gereğidir. Emreden Yüce Allah hakîm olduğuna göre, emri de ancak güzel olana yönelik gerçekleşecektir. Kötü olanı (kubh) yasaklaması da aynı şekildedir.27 Ancak Matüridî ulemasının çoğuna göre aklın iyi ve kötüyü bilmesi ancak genel itibariyledir yoksa özel yani tek tek nesneler veya olaylar için söz konusu değildir. Çünkü münferiden her bir eşya hakkında hüküm vermek şeriatın inisiyatif alanına girmektedir. ${ }^{28}$ Ancak bu görüş yukarıdaki ifade ile birleştirildiğinde hakkında delil olmadıkça kısmıyla örtüşmektedir. Öte yandan müteşabih ayetlerin bilinmesi de yine Matüridîlere göre aklen mümkün değildir. Şayet mümkün olsaydı öncelikle Hz. Peygamber'in aklıyla onların anlamlarını bilmesi gerekirdi. Bu yüzden olacak ki, Hz. Peygamber ne o ayetleri açıklama yoluna gitmiş ne de sahabeden birisi bu ayetlerin tefsirini O'na sormuştur. ${ }^{29}$

\section{Akıl ve Duyular}

Kelâm ilminde duyular görme, işitme, tatma, dokunma ve koklama şeklinde beşe ayrılır ve her bir duyunun ancak kendi alanında işlev göreceği özellikle

25 Bk. el-A'raf 7/179; ayr. bk. Ebü'l-Leys es-Semerkandî, et-Tefsîr, Beyrut 1427/2006, Daru'lKütübi'l-İlmiyye, I, 319; Alaeddin el-Üsmendî, Lübâbü'l-Kelâm, nşr. Said Özervarlı, İstanbul 1495/2005, İsam, s. 47-48, 101-102.

"قال أصحابنا رحمه اللة: يمكن الوقوف به (العقل) عالى ذلك، حتى إن الله تعالى لو أخلى العالم عن الرسل لكان الايمان بالله

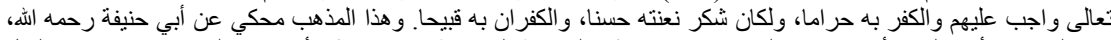

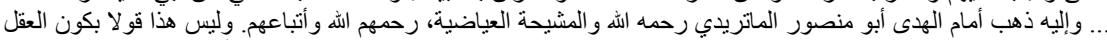

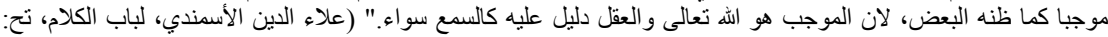

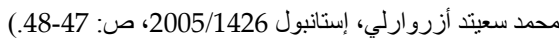

26 Ebü'l-Münteha, el-Külliyât, Beyrut 1412/1992, s. 617-620.

27 Cessas, Ahkâmü'l-Kur'ân, I, 32; Ebü'l-Berekât en-Nesefî, Şerh, s. 486-498.

28 Ebü'l-Muîn en-Nesefî, et-Temhîd fì usûli'd-dîn, nşr. Abdulhay kâbîl, Kahire 1407/1987, Daru's-Sekâfe, s. 43-44.

29 Matüridî, Te'vilât, IV, 84.

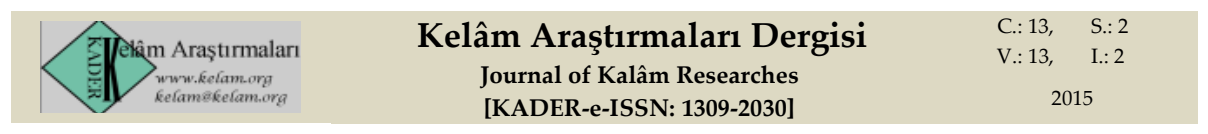


belirtilir. Bunun anlamı, görme duyusu ile işitilmeyeceği, işitme duyusu ile tat alınamayacağı, dokunma duyusu ile görülemeyeceğidir. Çünkü her bir duyu Yüce Allah tarafından, belli ve belirlenmiş bir alanda işlev görmek üzere yaratılmıştır. Ancak bazı duyuların eksilmesi ile diğer duyuların meydana gelen açığı bir ölçüde kapatmak için gelişmesi de söz konusu olabilir. Sözgelimi görmeyen bir kimsenin insanları dokunma duyusu ile tanıması veya koklama duyusu ile eşyayı veya kişileri kokularından ayırt edebilmesi mümkün olabilmektedir.

Kelam düşüncesinde duyular bir hüküm aracı olarak değil, bilgi/veri toplama mekanizması olarak görülmüşlerdir. Duyulardan gelen verilerin hükme dönüşmesi, ancak kalp veya akıl ile gerçekleşmektedir. Dolayısıyla ne akıl ne de duyular birbirlerinden bağımsız hüküm elde etme imkanına sahiptirler. Hem duyular hem akıl birbirlerine sıkı sıkıya bağımlıdırlar. Diğer bir deyişle aklın duyulara ihtiyacı ile duyuların akla ihtiyacı aynı orandadir.

\section{Akıl ve Haber}

Kelâmda haber, aktarma yoluyla insanda hâsıl olan gerçeğe uygun bilgi şeklinde tanımlanır. Gerçeğe uygun olması haberin doğru olduğu, aktarma şeklinde gerçekleşmesi de dış bir araç ile insana bilginin ulaşması anlamına gelir. Çünkü kişinin duyularını ve aklını kullanarak bizzat kendi çabasıyla elde ettiği bilgi haber olarak değerlendirilmez. Bir bilginin haber olabilmesi için kişinin kendi dışında bulunan bir aracı vasıtasıyla onu elde etmesi gerekir. Bu bilginin gerçeğe uygun düşmesi haberin doğru, gerçeğe uygun düşmemesi ise yalan olması anlamına gelir. Bu durumda aracı konumunda bulunan şahıs haberin gerçeğe uygun düşüp düşmemesine göre ya doğru ya da yalancı olarak adlandırılır. Haber, hayatın içinde çok önemli bir yere sahiptir. Kişinin anne, baba, amca, dayı, hala ve teyze gibi aile ve akrabalarını bilmesi tamamıla habere dayalı bir bilgidir. Diğer bir deyişle kişinin geçmişi ile ilgili bütün bilgiler haber yoluyla gelmektedir. ${ }^{30}$

Peygamberlere melek aracılığı ile gelen vahiy de haberdir. Aynı şekilde peygamberin kendisine gelen bu vahyi insanlara aktarması ve onların da diğer insanlara aktarması haber kategorisinde değerlendirilir. Bu çerçeveden bakıldığında dinin esasları bütünüyle haber türü bir bilgidir. Ancak bu bilgi güvenilir bir melek aracilığı ile geldiği ve yine güvenilir bir kişi olan peygamber vasıtasıyla insanlara duyurulduğu için gerçeğe uygun doğru haber kabul edilir.

Kelâm kaynaklarında haberler kesinlik hiyerarşisine göre birkaç sınıfa ayrılır. Kesinlik düzeyinin en üst noktasında mütevatir haber yer alır. Mütevatir haber, yalanda birleşmeleri adeten imkânsız görülen bir topluluğun verdiği haberdir. Burada iki şart söz konusudur: Birincisi bir topluluk olması

30 Nureddin es-Sabunî, el-Kifâye, nşr. Muhammed Aruçi, İstanbul 1412/2011, s. 80.

\begin{tabular}{|ccc} 
Kelâm Araştırmaları Dergisi & C.: $13, \quad$ S.: 2 \\
Journal of Kalâm Researches & V.: $13, \quad$ I.: 2 \\
[KADER-e-ISSN: 1309-2030] & 2015
\end{tabular}


ikincisi ise bu topluluğun yalanda birleşmelerinin adeten imkânsız görülmesidir. Bu yolla gelen bilgiler doğru ve kesin bilgi kabul edilir. Bu bilgiye dayanan hükümler de dinde vacip veya farz hükmündedir. Mütevatir olmayan haber, tek kişinin veya yalan üzere birleşmesi imkan dahilinde olan bir topluluğun verdiği haberdir. Bu tür habere âhâd haber adı verilir. Kelâm ilminde tek bir şahsın verdiği haber kesin kabul edilmez ve ona dayanan hüküm de kesin hüküm olarak görülmez. Bir haberin mütevatir veya âhâd haber olması, haberin gerçekliği ve gerçekleşmişliği ile alakalıdır. Kelâmî ifade ile haberin sübût yönünü gösterir. Bunun yanında haberin içeriğinin açık ve anlaşılır olması da önemlidir. Buna kelâm dilinde haberin delâlet yönü denilir. Kesin olan mütevatir bir haberin açık ve anlaşılır olmaması da dinde kesin hüküm kaynağı sayılmasına engel teşkil eder. Sözgelimi İhlas suresinde geçen "Allah birdir" ifadesi hem mütevatir yani kesin hem de açık ve anlaşılır bir ifadedir.

Aklın haber karşısındaki konumu, duyular karşısındaki konumuna benzer. Haber yoluyla gelen verilerin değerlendirilmesi ve bunların makuliyet ölçeğine vurulması aklın imkân alanına girer. Makul görülmeyen bir haber, mütevatir dahi olsa akıl tarafından reddedilmesi her zaman mümkündür. Örneğin müşrikler putları reddedip ilahları tek bir ilaha indirgeyen İslam inancını makul bulmamışlardır. Aynı şekilde Hıristiyanlar da teslisi reddeden tevhid inancını kendilerine göre makul bulmamışlardır. Müslüman aklı açısından değerlendirildiğinde ne birden fazla ilahı ifade eden putçuluk ne de üç ilah imajı uyandıran teslis inancı makul görülebilir. Görünen o ki, akıl aslında hakikati desteklediği gibi putçuluk ve teslisi de destekleyebilmektedir. Nitekim puta tapanları veya teslise inananları akılsız saymıoruz. Bu yüzdendir ki, Matüridî kelamcıları inanmayı bir tercih olarak görmüşler ve burada hareketle aklî çıkarsamada (istidlal) bulunmaksızın inanan kişinin (mukallit) imanının geçerli olduğu kanaatine varmışlardır. Çünkü bu kişi her ne kadar aklî bir delile dayanmasa bile, peygamberin getirdiğini tasdîk etmek ve kalbinde bir şüpheye yer vermemek suretiyle kesin imana ulaşmıştır. ${ }^{31}$

Öte yandan haberin duyularla da yakın ilişkisi bulunmaktadır. Her ne kadar vahiy gibi gaybî olan haberler, farklı değerlendirilse de müşahede/şehadet âlemine dair haberlerin duyulara dayanması zaruridir. Yani beş duyudan biri ile elde edilen bir veri, kişiden kişiye aktarılma işlemine tabi tutulmasıyla birlikte habere dönüşmüş demektir. Bu da gösteriyor ki akıl ile duyular ve haber arasında son derece girift ve sıkı bir bağ bulunmaktadır.

\section{Akıl ve Gayb}

Gayb, insanın bilemediği, şehadet ise insanın bilebildiği alan olarak tanımlanır. ${ }^{32}$ Öte yandan gayb için beş duyunun ulaşamadığı ve yetersiz kaldığı alan şeklinde

\footnotetext{
31 Ebü'l-Muîn en-Nesefî, Tebsıra, I, 42.

32 Ebü'l-Leys es-Semerkandî, et-Tefsîr, I, 494.
}

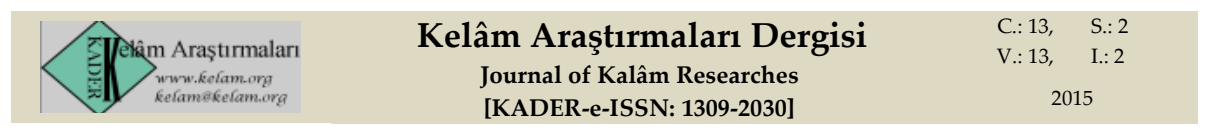


bir tanım da mevcuttur. Dolayısıyla gayb âlemi, bütünüyle habere dayalı bir bilgi alanıdır. Gaybdan alınan haberler konusunda akıl, ancak makul bulmak ya da bulmamak şeklinde bir hüküm ortaya koyabilir. Ebü'l-Leys es-Semerkandî, kesin bilgi denilen yakîni, aynî yakîn, haberî yakîn ve delalî yakîn şeklinde taksime gitmiştir. Aynî yakin gözle/duyularla bir şeyin algılanması, haberi yakîn duyuların ulaşamadığı alandan bilgi verilmesi, delalî yakin ise ateşin dumanı gibi bir şeyin görülen işaretinden hareketle hükme varılmasıdır. ${ }^{33}$ Semerkandî'nin haberi yakîni duyuların ulaşamadığı alandan bilgi verilmesi şeklindeki tanımı, gaybın tümüyle habere dayalı olduğu yargısını destekler mahiyettedir. Öyleyse duyuların ulaşamadığı alan, gaybdan başkası değildir.

Gaybî alandan elde edilen bilginin duyular yoluyla olup olmadığını tespit çok kolay değildir. Ancak bazı gaybî bilgilerin duyulara dayanması ihtimali de söz konusudur. Sözgelimi "Aynı şekilde kesin inananlardan olsun diye biz göklerin ve yerin mülkünü/yönetimimiz altındaki olgu ve olayları İbrahim'e gösteriyorduk" 34 mealindeki ayet ile "Ayetlerimizi göstermek için bir gece kulunu Mescid-i Haram'dan etrafını mübarek kıldığımız Mescid-i Aksâ'ya götüren Rabbin her türlü noksandan münezzehtir"35 ayetleri sanki Hz. İbrahim ve Hz. Peygamber'e görme yoluyla bir takım şeylerin gösterildiğini ifade etmektedir. Öte yandan Hz. Musa'nın Tur dağından işittiği ses de aslında gaybî bir ses olarak değerlendirilebilir. Bu durumda gaybî bir takım bilgilerin duyular yoluyla elde edilmesi imkanı da bulunmaktadır. Ancak Hz. Musa'nın yaratılmış sesleri işittiği, Hz. Peygamber'in İsrâ ve Miracının rüyada gerçekleştiği rivayetleri hesaba katılırsa duyuların bu alanda pek yerinin olmadığı sonucuna da varılabilir.

Öte yandan gaybî bilgi de derece derecedir. Allah'ın bildiği ile meleklerin, cinlerin veya insanların bildiği birbirinde farklılık arz etmektedir. Bu yüzden gaybî bilgide görecelik hali de söz konusudur. Sözgelimi Matüridî, "Biz insanı yarattık, onun kendi nefsine ne tür bir vesvese verdiğini de biliriz" 36 mealindeki ayeti yorumlarken insanın içinden gizlice geçirdiği duyguları sadece Allah'ın bilebileceğine dikkat çeker. Çünkü burası ancak Allah'ın bilebileceği bir alandır. Hafaza melekleri dahi insanın içinden geçen duygu ve düşünceleri bilemez, onların yazdıkları insanın lafza ve fiiliyata döktükleri hususlardır. ${ }^{37}$ Buradan hareketle aklın kavrayabileceği bilgiler, ancak söz veya eyleme dökülmüş bilgiler olabilir, değilse gaybı bilmesi ve orada cereyan eden hususlardan haberdar olması söz konusu değildir.

Ebü'l-Leys es-Semerkandî, et-Tefsî̀, I, 90.

el-En'âm 6/75.

el-İsrâ 17/1.

Kaf, 50/16.

Matüridî, Te'vilâtü Ehli's-Sunne, IV, 559.

\begin{tabular}{|c|c|c|}
\hline Siâm Araştırmaları & $\begin{array}{l}\text { Kelâm Araştırmaları Dergisi } \\
\text { Journal of Kalâm Researches } \\
\text { [KADER-e-ISSN: 1309-2030] }\end{array}$ & $\begin{array}{cc}\text { C.: } 13, & \text { S.: } 2 \\
\text { V.: } 13, \quad \text { I.: } 2 \\
2015\end{array}$ \\
\hline
\end{tabular}




\begin{abstract}
Akıl ve İman
İman, Sünnî kelamcılara göre kalp ile tasdik, Hanefî fakihlerine göre dil ile ikrar kalp ile tasdik; Ehl-i Hadîs, Mu'tezile, Zeydiyye ve Haricilere göre ikisine ilaveten bedenle yapılan amel (amel bi'l-cevârih), Kerramiye'ye göre ise dünyada dil ile ikrar ahirette ise kalp ile tasdiktir. Cehm b. Safvân'a göre iman kalp ile bilmek (marifet), Huseyin b. Fadl el-Becelî́ye göre ise iman sadece tasdik etmektir. Bu son son görüş sahiplerinin her ikisi de aslında imanın kalbin bir ameli olduğunda ittifak etmişlerdir. Bazı sufiler ise iman dilin ikrarı ve kalbin ihlası görüşünü ileri sürmüşlerdir. Sülemî, dilin marifeti ikrar, kalbin marifeti tasdîk, ruhun marifeti ise yakîndir demiştir. ${ }^{38}$
\end{abstract}

Bütün bu farklı tanımların ortak noktası her birinin imanı kalp ile ilişkilendirmesidir. Öyleyse iman işinde kalbin birinci derecede rolü ve önemi vardır. Kalp bu tasdik işlevini yerine getirirken ya akıldan yardım alacaktır ya da bir fonksiyonu olan akıl şeklinde bu tasdik gerçekleşecektir. Aklı bir cisim ve cevher kabul edenlere göre aklın hüküm vermesiyle kalbin tasdiki gerçekleşir. Aklı bir fonksiyon olarak görenlere göre ise kalbin tasdiki bizatihi akıl şeklinde gerçekleşir. Dolayısıyla akleden insan aynı zamanda tasdik eden insandır. Kur'an'da geçen "akletmiyorlar mı?" şeklindeki ifade bu noktada tam da yerini bulmaktadır. Akletmeyenler, tasdikten kaçınanlar dolayısıyla câhillerdir. Nitekim iman tanımında kalbin bu kadar öne çıarılması ve Kur'an'da aklın bir isim olarak değil de fiil olarak kullanılması ayrıca el-Hac Sûresinde kalbin akletmesinden bahsedilmesi, aklın bir fonksiyon/fiil yani tasdik olayı olduğu fikrine bizi götürmektedir.

Bu durumda iman akılla değil, kalple gerçekleşmekte ancak gerçekleşmesi bizatihi akıl olarak tezahür etmektedir. İslam öncesinin "Cahiliyeye" olarak isimlendirilmesi ve Ebû Cehil'e bu lakabın verilmesi bu kanıı güçlendirmektedir. Öte yandan imanı kalbin fiili, ameli de bedenin fiili şeklindeki tanımlamalar da bu tespiti doğrular ve destekler mahiyettedir. ${ }^{39}$ Çünkü kalbin ameli bir ölçüde kalbin fiili anlamına gelir. Kalbin fiili düşünme ve derinlemesine anlama (tefekkür ve teemmül) şeklinde tezahür eder. Bu iki eylemi gerçekleştiremeyen küfre düşmeye mahkûm olur ve onun kalbi mühürlenir. Nitekim kelamda sadece imanın değil, küfür, şirk, günah ve takvanın bulunduğu ve şekillendiği yer olarak kalp görülür. ${ }^{40}$

Bu noktada felsefe ile kelam arasındaki temel fark terminoloji farkıdır. Kelamcıların kalp istılahına karşın felsefeciler aklı kullanmakta, benzer şekilde kelamcıların ruh ıstılahına karşın felsefeciler nefsi tercih

38 Abdulkahir el-Bağdadî, Usûlü'd-dîn, s. 248-250; Ebü'l-Muîn en-Nesefî, Tebstra, s. 38; Fahreddîn er-Razî, et-Tefsîr, I, 24-25; Sülemî, el-Mukaddime fi't-Tasavouf, nşr. Yusuf Zeydan, Kahire 1407/1987, Mektebetü'1-Külliyeti'l-Ezheriyye, s. 37.

39 Fahreddîn er-Razî, et-Tefsîr, I, 23.

40 Matüridî, Te'vîlât, I, 16; III, 529-530; Zemahşerî, el-Keşşaf, Kahire ts., el-Mektebetü'tTevfîkiyye, III, 177, 361.

\begin{tabular}{|c|c|c|}
\hline 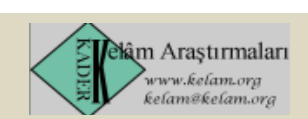 & $\begin{array}{l}\text { Kelâm Araştırmaları Dergisi } \\
\text { Journal of Kalâm Researches } \\
\text { [KADER-e-ISSN: 1309-2030] }\end{array}$ & $\begin{array}{cc}\text { C.: } 13, \quad \text { S.: } 2 \\
\text { V.: } 13, \quad \text { I.: } 2 \\
2015\end{array}$ \\
\hline
\end{tabular}


etmektedirler. Felsefecilerin aklı bir hüküm mercii ve kaynağı olarak görmesi kendi ıstılahları açısından isabetli olmakla birlikte, kelamcıların kalbi hüküm mercii görmeleri de yine kendi ıstılahları açısından isabetlidir. Eskilerin deyimi ile لا مشاحة في الاصطلاح yani terminolojide tartışmak anlamsızdır. Dolayısıyla kudemâdan bazısı ile müteahhirûn kelamcılarının aklı felsefeciler gibi bir garîze veya cevher olarak görmeleri ve bundan hareketle imanın akıl tarafından gerçekleşen tasdik ile olacağı kanısına varmaları sadece bir ıstılah farkını gösterir. Her iki durumda da imanda bir değişim söz konusu değildir. Değişen iman etme aracının aklın kaynağı olan kalp ya da bizatihi aklın kendisi olup olmamasıdır.

"İman etmede kalbin veya aklın rolü nedir?" sorusuna mezheplerin farklı cevapları olmuştur. Mu'tezile aklı, Ehl-i Hadîs ise nassı öne çıkarmış, Sünnî kelamcılar ikisi arası bir yerde durmayı tercih etmiş görünmektedirler.

Mu'tezile'ye göre akıl yürütmeksizin yani bir delile dayanmaksızın yapılan iman kişiyi azaptan/cehennemden güvenli bir konuma getirmediği gibi, böyle bir imanın da faydası yoktur. Onlara göre bilgi ya zorunlu ya da istidlalîlidir, üçüncü bir bilgi türü bulunmamaktadır. Söz konusu zorunlu ya da istidlalî bilgiden her hangi birisine dayanmayan bir imanın geçerliliği ve faydasından söz edilemez. Zorunlu bilginin olmadığ ancak akıl yürütme ile gerçekleşebilir. Zaten Allah'ın bilinmesi zorunlu değil, istidlalî bilgiye dayanır. Eğer marifetullah, bilginin kendiliğinden oluşması anlamına gelen zorunlu bilgiye dayansaydı bütün akıl sahiplerinin iman etmesi gerekirdi. Akıl yürütmenin olmadığı bir durumda ortaya çıkan bilgi yani iman ancak taklidî bir imandır ki, bunun kişiye yönelik dünyevî ve uhrevî bir faydası düşünülemez. Sonuç itibariyle taklidi iman sahih değildir, çünkü bu bir kişinin başka bir kişiyi taklit etmesi anlamına gelir. Halbuki Hz. Ali'nin dediği gibi, hakikat insanlarla değil, insanlar hakikatlerle bilinir. Ancak Mu'tezile peygamber ile avam tarafından bir alimin taklidini ayrı değerlendirmektedir. Peygamberin nübüvveti mucize deliline nazar bilindiğinden taklit kapsamından çıkmaktadır. Avamın alimi taklidi ise, itikadî konularda değil, sadece ameli konularda söz konusu olur. Bu da taklit değil, âlimin sözüyle amel etmektir. ${ }^{41}$

41 Marifetullah konusunda Mu'tezile içinde başını Nazzam'ın çektiği Ashâbü'l-Meârif denilen grup bunun zorunlu bilgi (el ilm ed-darûri) ile gerçekleşeceği görüşündedir. Kadî Abdulcebbar, Şerh, s. 50-63; el-Muhtasar fì usûli'd-dîn, Muhammed Ammara, Resâilü'l-adl ve't-tevhîd, Kahire ts., Daru'1-Hilal, I, 170-171.

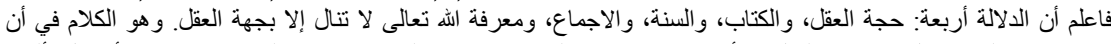

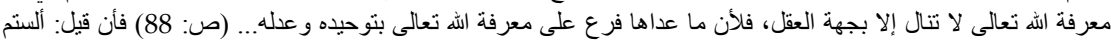

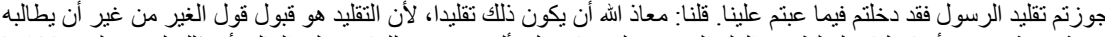

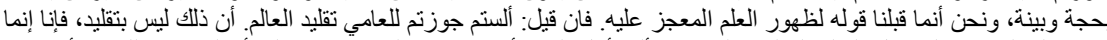

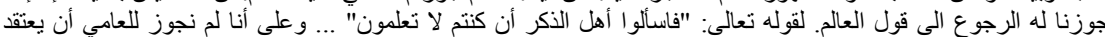

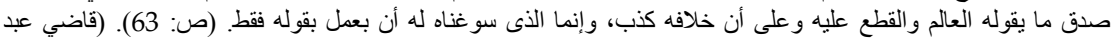

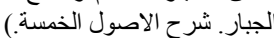

\begin{tabular}{|c|c|c|}
\hline 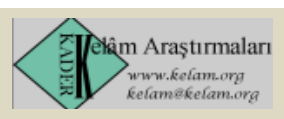 & $\begin{array}{l}\text { Kelâm Araştırmaları Dergisi } \\
\text { Journal of Kalâm Researches } \\
\text { [KADER-e-ISSN: 1309-2030] }\end{array}$ & $\begin{array}{cc}\text { C.: } 13, & \text { S.: } 2 \\
\text { V.: } 13, \quad \text { I.: } 2 \\
2015\end{array}$ \\
\hline
\end{tabular}


Ehl-i Hadîs grubuna göre ise kişinin peygamberin getirdiği hususları tasdîk etmesi ve itaatini ortaya koyması iman etmesi için yeterlidir. Sünnî kelamcılar bu konuda Mu'tezile yaklaşımı ile Ehl-i Hadîs yaklaşımı arasında gidip gelen bir tavır sergilemişlerdir. Ebü'l-Hasan el-Eş'arî Mu'tezile'ye yakın bir konumu tercih ederken İmam Matüridî'nin öğrencisi olan Ebü'lHasan er-Rüstüğfenî Ehl-i Hadis'in çizgisini benimsemiştir. Bu noktada Eş'arî delile dayanmaksızın inanan kişiyi her ne kadar mümin ismini almaya layık görmese de ona müşrik veya kâfir denmesini doğru bulmamıştır. Rüstüğfenî ise her mesele de aklî delile dayanmanın gerekmediğini, peygamberin getirdiği hususların tasdîki ile imanın gerçekleşeceğini ileri sürmüştür. Diğer Eş'arî ve Matüridî kelamcılarının kahir ekseriyeti, akıl yürütmeye dayanmayan imanın geçerli olduğunu ancak kişinin akıl yürütmeden kaçması dolayısıyla isyan etmiş sayılacağını ve bu yüzden günahkâr olacağını ileri sürmüşlerdir.

Bu noktada akıl yürütmenin yöntemi hususunda da farklılık söz konusudur. Mu'tezile ve Sünni kelamcılardan bazıları akıl yürütmeyi nasslardan bağımsız, aklın verilerine dayanması gerektiğini savunurken, diğerleri akıl yürütmenin naslardan hareketle ve onların gösterdiği ve çizdiği doğrultuda olması gerektiğini ileri sürmüşlerdir. Birincilere göre nasları getiren peygamberin nübüvvetini kabul etmek ancak akıl yoluyla gerçekleşmektedir. Nitekim davete muhatap olan insanlar peygamberin gösterdiği mu'cizeye veya kişilik özelliklerine bakarak akıl yürütmede bulunmaktadırlar ve sonuçta ya tasdîk ya da inkâr şeklinde aklî bir hüküm ortaya koymaktadırlar. Naslardan hareket edilmesi gerektiğini düşünen ikinci grup ise, aslında nasların bizzat kendilerinin öz ve özet olarak akıl yürütme yöntemini barındırdığını, akla düşen ise bunları mufassal bir şekilde sunmak ve açıklamak olduğunu dile getirmişlerdir.

Akıl yürütme ile ulaşılan imanî sonuçlar ise dinî/şerî konular olmayıp tamamen aklın naslar olmaksızın da ulaşabileceği, Allah'ın varlığı ve birliği, evrenin sonradan oluşu (muhdes) ve nimet verene şükretmenin gerekliliği şeklindeki bilgilerdir. Zaten bu noktada Mu'tezile ve Matüridîler peygamber gönderilmese dahi kişi bu hususlardan sorumludur kanaatindedirler. Eş'ariler iman için bunları gerekli görseler bile peygamber gelmeksizin kişinin bunlara imanının vücubiyetini öngörmemektedirler. ${ }^{42}$

\section{Değerlendirme ve Sonuç}

Aklın tanımı, mahiyeti ve insandaki yeri konusunda öyle görünüyor ki, hiçbir branş ve zihniyet grubunda ittifak söz konusu değildir. Bunun temel sebebi, insanın henüz ne biyolojik ne de psikolojik tarafının tam olarak keşfedilememiş olmasıdır. Keşfedilmesinin imkânı dahi tartışmaya açıktır. Bu kadar farklı düşünce ve hatta karmaşa içinde aklın tanımı, mahiyeti ve

42 Abdulkahir el-Bağdadî, Usûlü'd-dîn, s. 254-255; Ebü'l-Muîn en-Nesefî, Tebsira, s. 38-61; Ebû Bekir İbnü'l-Arabî, Kanûnü't-te'vîl, s. 176-178; Cürcanî, Şerhu'l-mevâkıf, I, 251-254.

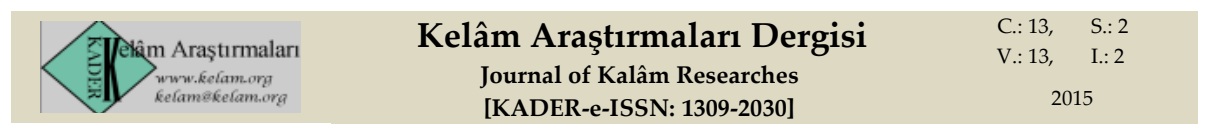


yeri konusunda açı ve her kes tarafından kabul edilebilir bir fikir ortaya koymanın zorluğu ortadadır.

Kur'an'da akılla ilgili bütün lafızların fiil kalıbında gelmesi, daha da önemlisi "Yeryüzünde hiç gezmediler mi? Bu sebeple onların akleden kalpleri, işiten kulakları olsun. Zira gözler kör olmaz, kör olan gögüuslerdeki kalplerdir." 43 Ayetinde aklın kalbe bağlanması ve adeta kalbin bir fonksiyonu/taalluku gibi görülmesi, bilgi mekanizmasında asıl olanın kalp olduğunu ortaya koymaktadır. Bu durumda akıl sadece kalbin bir fonksiyonu kelamî tabirle taallukudur. Bu durumda kulak için işitmek ne ise kalp için akletmek odur. Ayette ayrıca hükmün sonucunun göz ve kulak ile değil, düşünen/akleden kalp ile belirlendiği açıktır. "Bu Kur'an alemlerin Rabbinin indirdiğidir. Uyarıcılardan olasın diye Ruhu'l-Emîn senin kalbine Arapça bir lisan ile onu indirmiştir"44 mealindeki ayet de yukarıdaki yargıyı destekler mahiyettedir. Çünkü Fahreddîn Razî'nin de ifade ettiği gibi kalp, aklın merkezi ve akıl da onun sevinç ve üzüntü gibi bir fonksiyonudur. Böylelikle kalp insanın hem akletmesinin hem de tercihte bulunmasının odağ konumundadır. ${ }^{45}$

Alg1 mekanizmasının unsurları arasında bir derece sıralaması yapanların aksine Kur'an'da bilgi elde etme vasitalarının derecelemeye tabi tutulmadığı diğer bir deyişle kuvvetli-zayıf ayrımı yapılmadığı görülür. Zira her birinin kullanıldığı yer ve durum diğerinden farklıdır. "Görmüyorlar mı ki biz suyu kuru ve otsuz yere sürüyoruz da o sayede ekin bitiriyoruz. Ondan hayvanları da kendileri de yiyor. Onlar hâlâ görmüyorlar mı?" 46 mealindeki âyette gözün dolayısıyla duyu organlarının önemi vurgulanırken, bir çok âyette de yerde ve gökte değişen olaylar sayılmak suretiyle insanın düşünmesi ve aklını kullanması sık sık vurgulanmıştır. ${ }^{47}$ "Onlar sağır, lâl, kördürler, bundan dolayı da düşünemezler (akledemezler)" 48 mealindeki âyette ise inkâr edenler gerçekte sağır, lâl, kör olmadıkları halde duyularını gereği gibi kullanmadıklarından bu şekilde nitelenmişler ve duyularını kullanmayanın aklını da kullanamayacağı sonucu ortaya konmuştur ki bu, hem duyu-akıl ilişkisini hem de bilgi edinme yollarının birinin diğerinden bağımsız olmadığını vurgulaması açısından önemlidir. Haber konusunda ise Allah'ın insanlarla kendisi arasında sözlü ilişkiyi sağlamak için gönderdiği kimselere "haber veren" anlaminda "nebi" diye isimlendirmesi bunun en güzel örneğidir. ${ }^{49}$ Kur'ân, kişinin sağlam duyuları, selim aklı ve doğru haber ile gerçek bilgi elde edebileceğini belirtirken, aklın ve duyuların verdiği

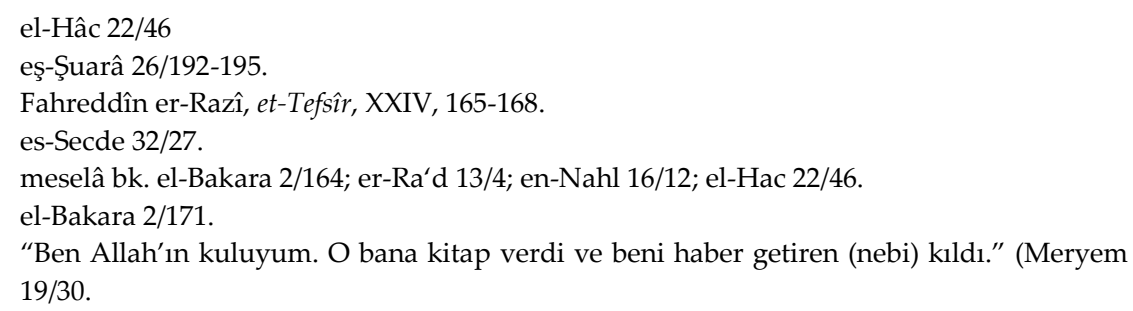

\begin{tabular}{|ccc} 
Kelâm Araştırmaları Dergisi & C.: $13, \quad$ S.: 2 \\
Journal of Kalâm Researches & V.: $13, \quad$ I.: 2 \\
[KADER-e-ISSN: 1309-2030] & 2015
\end{tabular}


bilginin sınırlı olması hasebiyle insanın sağlam ve her zaman doğru kalabilen bir bilgi kaynağına ihtiyacı olduğunu dile getirmiştir. Kur'ân'ın söz konusu ettiği bu bilgi kaynağı vahiydir. Bütün varlık ve olayları ezelî ilmi ile kuşatan Allah'tan gelen bir bilgi olması nedeniyle vahiy, insanın en doğru ve kesin bilgi kaynağıdır. ${ }^{50}$

Kur'ân'da "kalb" ve "fuâd" kelimeleri incelendiği takdirde bunların, aklın bir başka adı, madeni, mekânı ve çıkış noktası olduğu görülür. ${ }^{51}$ Duyular, kalb, fuâd gibi kelimelerin sık sık bir arada zikredilmesinden bunların hep birlikte kullanılması durumunda doğru bilgi elde edilebileceği sonucu çıkarılabilir. Bazı kelâm âlimlerinin aklı ve onun ürünü olan nazarî bilgiyi ön plana çıkarması gibi52 Sufilerden İbn 'Arabî'nin keşfi diğer bilgi kaynaklarından daha üstün ve güvenilir sayması Kur'ân'1n bu tutumuna uygun düşmemektedir. Hâlbuki Sufi kesimden İmam Rabbânî (ö. 1034/1624) keşif ile içtihadı (keşfî bilgi ile nazarî bilgiyi) aynı seviyede görmüş ve içtihattaki isabet ve yanılmanın keşifte de söz konusu olabileceğine dikkat çekmiştir. Benzer yaklaşım İbn Haldûn' da da bulunmaktadır. ${ }^{53}$

Kelam düşüncesinde kalbin esaslı bir yeri vardır. Hem imanî hem de amelî konularda muhatap kalptir. Ancak kalbin tezahürü ve bilinirliği onun bir fiili/fonksiyonu olan akıl iledir. Dolayısıyla kalp, alg1 mekanizmasının başı ve temelidir. Bu yüzdendir ki, imanın gerçekleşmesinin şartı olan tasdik ile küfrün tezahürü olan inkârın çıkış noktası ve menbaı kalptir. Nitekim dinî anlamda gafletin ve cehaletin merkezi de kalp olarak görülmektedir. ${ }^{54}$ Aklî çıkarsamalar her ne kadar kelam ilminde delil olarak kabul edilse bile, imanın kabul yeri olarak hemen her mezhep mensubu kalbi görmüşlerdir. Sözgelimi Matüridî kelam kitaplarında bilgi kaynakları olarak duyular, haber ve akıl yer alır, ancak imanın tanımı söz konusu olduğunda kalbin tasdiki ifadesi kullanılır. Yukarıda geçtiği gibi Mu'tezile, Kerramiye, Eş'ariye ve diğer tüm mezhepler için de aynı durum söz konusudur. Öyleyle akıl, her ne kadar bazılarınca haber ve duyular gibi insana bilgi sağlayan bir araç olarak görülse de nihai karar mercii kalptir.

Akletmenin önündeki en büyük engel taklit olarak görülmektedir. Çünkü insan, güç ve bilgi bakımından kendinden üstün gördüğü kişilere yaranmak veya onlardan yararlanmak için çoğu kere onları birebir taklit etme eğilimindedir. Günümüzde modayı takip, sanatçılara veya meşhurlara öykünme bunun en çarpıcı örneğidir. Teknolojik ve bilgiye çok hızlı ulaşma

Yusuf Şevki Yavuz, Kur'ân-ı Kerim'de Tefekkür ve Tartı̧ma Metodu (Bursa 1983) s. 196. bk. el-Ahzab 33/32; eş-Şuara 26/89; el-İsra 17/36; es-Secde 32/9.

bk. İbn Fûrek, Mücerredü makâlâti'ş-Şeyh Ebi'l-Hasan el-Eş'arî (nşr. Daniel Gimaret, Beyrut 1987), s. 319-320; Cüveynî, eş-Şâmil, nşr. Helmut Klopher, Kahire 1988-1989, s. 30; Fahreddîn er-Râzî, Muhassalü'l-efkâri'l-mutekaddimîn ve'l-müteahhirîn, nşr. Tahâ Abdurrauf Sa'd, Kahire ts., Mektebetü'l-Külliyâti'l-Ezheriyye, s. 51.

53 İmam Rabbânî, el-Mektûbât, Mekke 1317 $\rightarrow$ İstanbul ts., Fazilet Neşriyat, I, 346; İbn Haldun, Şifaü's-sâil li tehzîbi'l-mesâil, nşr. Muhammed b. Tâvît et-Tancî, İstanbul 1958, s. 61, 69.

54 bk. Fahreddîn er-Razî, et-Tefsîr, XXIV, 167.

\begin{tabular}{|ccc} 
Kelâm Araştırmaları Dergisi & C.: $13, \quad$ S.: 2 \\
Journal of Kalâm Researches & V.: $13, \quad$ I.: 2 \\
[KADER-e-ISSN: 1309-2030] & 2015
\end{tabular}


gibi yüksek düzeyli gelişmelere rağmen Hz. Âdem'den bugüne insanın eğilim ve davranışlarında çok fazla değişen bir şey olmadığından, güçlü olanı taklit hala geçerliliğini ve gerçekliğini korumaktadır. "Yüce Allah peygamberliği kime vereceğini en iyi bilendir" 55 ayetinin açılamasında Ebû Mansur el-Matüridî'nin dediği gibi peygamber belirlemede Yüce Allah buna uygun şekilde peygamberleri orta sinıf insanlardan seçmiştir. Şayet Yüce Allah peygamberleri mal ve mülk olarak toplumun ileri gelenlerden seçseydi, insanlar hiçbir delil istemeksizin ve ispat beklemeksizin onlara tabi olurlard1. Çünkü insanlar çoğu kez ileri gelenleri taklit etme eğilimindedirler. Ancak orta kesimden peygamberler seçilince insanlar onlardan delil istemeye ve davasını ispat etmesi beklentisinde olmuşlardır. Böylece inandıkları ve sözlerine itimat ettikleri kişinin davasına tabi olmuşlardır. Öte yandan bu sinıftan seçilen peygamber sadece Yüce Allah'tan gelen emir ve yasakları dikkate alır ve kendi iradesini de kullanarak bunları uygular. Zira kişinin peygamber olması ve korunmuşluk (ismet) sıfatı, iradesinin yok sayılması ve imtihan dışı tutulması anlamına gelmez. Zaten bir peygamberin örnek olabilmesi için aklını, iradesini ve bundan doğan insanı gücünü kullanması gerekir. Peygamberlerin melek değil de insan olarak gönderilmesinin asıl hikmeti de bu olsa gerektir. ${ }^{56}$

Şehristanî ise bunun aksine aklın toplumsal yapının işleyişini düzenlemede müstakil olamayacağı noktasında dikkat çeker. Ona göre insan, düzen ve huzur içerisindeki bir toplumda yaşamaya muhtaçtır. Ancak söz konusu toplum, yardımlaşma ve çatışma (تعاون و تمانع) armonisi içerisinde kurulur ve devam eder. Toplum içinde oluşan anılan yardımlaşma ve çatışmanın sınırlarının belirlenmesi ise ya toplumsal uzlaşma veya dişarıdan bir kanun ile mümkündür. Her insan tekinin ilahî vahiy alması veya kendi kendine kanun oluşturması adeten mümkün olamayacağından toplumsal düzeni ve huzuru sağlayacak peygamber aracılığı ile Yüce Allah'ın gönderdiği bir yasal zemine ihtiyaç bulunduğu açıktır. ${ }^{57}$

Matüridî ve Şehristanî'nin dikkat çektiği yukarıdaki hususlar göz önünde bulundurulduğunda insanın kendi aklıyla iman etmesi aklen mümkün gözükmekle birlikte adeten gerçekleşme imkânı tartışmaya açıtır. Nitekim özellikle Sünnî kelamcılar, insan fiillerinin oluşumunu dikkate alarak imanın

55 el-En'am, 6/124.

56 Matüridî, Te'vilât, II, 171-172.

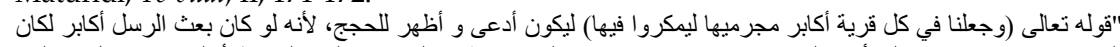

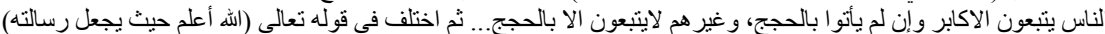

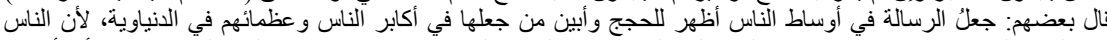

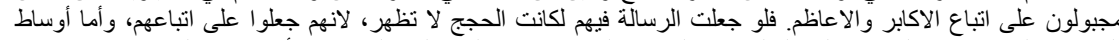

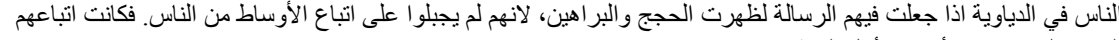

57 Şehristanî, Nihâyetü'l-ikdâm, s. 238.

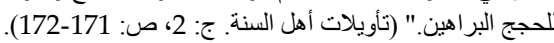

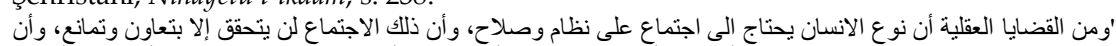

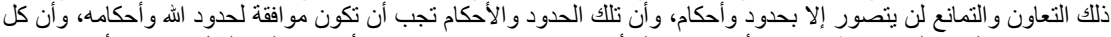

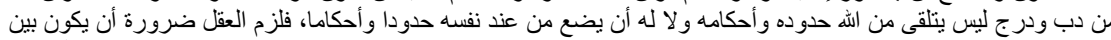

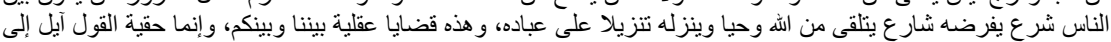
تعيين الثارع." الثهرستاني، نهاية الإقدام، بيروت 2004/1425، تُ تُ أحمد فريد. ص: 238.

\begin{tabular}{|c|c|c|}
\hline Siĝm Arasttırmaları & $\begin{array}{l}\text { Kelâm Araştırmalari Dergisi } \\
\text { Journal of Kalâm Researches } \\
\text { [KADER-e-ISSN: 1309-2030] }\end{array}$ & $\begin{array}{cc}\text { C.: } 13, \quad \text { S.: } 2 \\
\text { V.: } 13, \quad \text { I.: } 2 \\
2015\end{array}$ \\
\hline
\end{tabular}


bir ilahî hidayet sonucu gerçekleştiği noktasında ittifak etmiş görünmektedirler. İnsanın fiilinin meydana gelmesinde ve iyi-kötü hükmü kazanmasında her ne kadar insanın iradesi/niyeti önemli rol oynuyorsa da fiilin varlık sahasına çıkması tamamıyla Allah'ın iradesine bağlıdır. Öyleyse iman etme fiilinde akıl sahibinin aklıyla niyet ve azmini ortaya koymasının yanında Allah'ın da o niyet ve azme göre bir yaratma işinde bulunması gerekmektedir. Özellikle Matüridî kaynaklar kişinin niyet ve azminin bulunduğu her yerde şayet şartlar ve imkânlar da oluşmuşsa Yüce Allah'ın söz konusu niyet doğrultusunda fiili yaratacağına neredeyse kesin gözüyle bakarlar. Zaten kişinin fiilinden sorumlu tutulması da bu yüzdendir. Mu'tezile mensupları her ne kadar insanı fiilinde özgür kabul etseler de, özellikle tevfik veya ismet şeklinde lutuf yollu bir açıklamaya gitmek durumunda kalmışlardır. Öte yandan Allah'ın kitap indirmek veya peygamber göndermek suretiyle gerçekleştirdiği hidayete/lutfa gelince, Mu'tezile bunu her ne kadar herkese şamil ve eşit düzeyde ve aklı devre dışı bırakmayan açıklama kabul etse de, imanda ve amelî konularda insanın dışarıdan destek almasını öngörmek bakımından Sünnî kesimden çok uzak bir noktada durmadığı açıktır.

Kelam ilminde iman-akıl ilişkisinde kişinin aklının ve iradesinin öncelikli ve önemli bir yeri bulunduğu inkar edilemez bir gerçektir ve zaten bütün mezhepler de farklı dozajlarda da olsa bunu kabul etmektedirler. Bununla birlikte aynı hususta Yüce Allah'ın kitap indirmek ya da peygamber göndermek şeklinde açık ve somut yol göstermesinin veya ilham/lütuf şeklinde kapalı ve soyut desteğinin de önemli bir payının olduğu göz ardı edilemez. Sonuç olarak kelam düşüncesinde akıl iman açısından üç temel noktasının altını çizmek gerekir:

1. Peygamber gelmese dahi akıl sahibi Allah'ın varlığını, birliğini ve kendisine verilen nimetin şükrünün edasını araştırma ve bilme imkânına sahiptir. Yapmadığ 1 takdirde sorumlu tutulur. $\mathrm{Bu}$ sorumluluğu Mu'tezile ve Matüridiler vacip düzeyinde görürken, Eş'ariler ilahî emir gelmedikçe vacipliğin söz konusu olamayacağını dile getirirler.

2. Peygamber geldiği takdirde akıl sahibi öncelikle peygamberin doğruluğunu aklıyla test etmeli, delillerini akıl süzgecinden geçirmelidir. Ancak ondan sonra peygamberin getirdiği davaya tabi olması söz konusu olur. Bu konuda her üç mezhep küçük farklılıklarla aynı düşünmektedir.

3. Hüsün ve kubuh denilen kişinin çevresini aklıyla bilmesinin imkânı konusunda ciddi ayrilıklar söz konusudur. Mu'tezile aklıyla kişi çevresindeki olgu ve olayların faydalı veya zararlı, iyi veya kötü, güzel veya çirkin olma noktasından değerlendirebilir hatta bu konuda hüküm koyabilir. Matüridîler ise her ne kadar kişi bu imkâna sahip olsa bile hüküm koyma yetkisi Yüce Allah'a aittir,

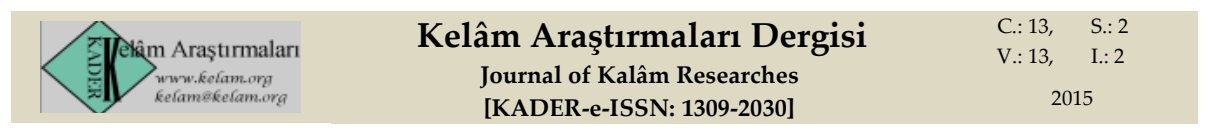


ancak onun hüküm koymasıyla sorumluluk/mükelleyefiyet unsurları oluşur. Eş'arîlere göre ise aklın böyle bir gücü yoktur. Allah'ın hüküm koymasına bağlı ve tabi olarak akıl bir değerlendirmede bulunabilir.

Bütün bunlardan sonra şu soruyu sormak gerekir: "Her türlü değer ve bilgiden yoksun aklın/kalbin bir hüküm ortaya koyması ne kadar mümkündür?" Bu soruya Kur'an'dan verilecek cevap Hz. Âdem yaratıldığında ve meleklerle karşı karşıya gelerek imtihana tabi tutulduğunda ancak Allah'ın ona isimleri öğretmesi ise imtihanı kazanmıştır. Öte yandan içinde bulunduğu kültür ve değerler silsilesinden bağımsız kişinin değer üretmesi ve hüküm ortaya koyması ne kadar mümkündür? Bunun cevabı İbn Tufeyl'in Hay b. Yekzân adlı kitabında saklıdır. Issız bir adada dünyaya gelen Hay, akli melekelerini kazandıktan sonra Allah'ın

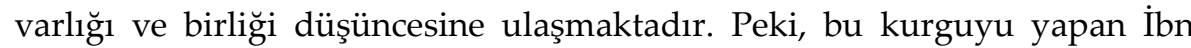
Tufeyl gibi Müslüman bir filozof değil de, sözgelimi ateist bir filozof olsaydı aynı sonuç ortaya çıkar mıydı? Son bir soru olarak kelam kitapların kişinin aklıyla ilk bilmesi gereken ilk hususun Allah bilgisi olduğu altı çizilerek vurgulanır. Bir kelam âlimi Kitap ve Sünnet gibi bir veri hafızası olmasaydı acaba bu hassasiyeti gösterebilir miydi?

Sonuç olarak dinin muhatabı akıllı insan olması hasebiyle bu alanda aklın devre dışı bırakılması asla söz konusu değildir. Akılla nassın yerlerinin uygun bir şekilde belirlenmesi ve ikisinin birlikte değerlendirilmesi ile hak ve hakikatin ortaya çıkacağı açıktır. Özellikle dikkate aldığımız Mu'tezile, Matüridiyye ve Eş'ariyye kelam mezheplerinin, her ne kadar aralarında bazı farklılıklar bulunsa da, birleştikleri nokta burasıdır. Öte yandan nassa bağllı̆̆g ile bilinen Ehl-i Hadîs mezheplerinden Henbelî mezhebi içinde bile metinlerin zahirine aşırı vurgulun neticede tecsim ve teşbihe yol açtığını mezhep içinden Ebü'l-Ferec İbnü'l-Cevzî tespit etmiş ve bu tür yaklaşımların mezhebin imamı Ahmed $b$. Hanbel veya mezhebin gelen anlayışı ile ilgisinin bulunmadığını dile getirmiştir. Nitetim o, mezhep içinde böyle bir tutumu benimseyenlere reddiye olarak kaleme aldığı Def'u şubehi'tteşbîh adlı eserinde onlara yönelik şöyle demektedir: "Sizler nakil erbabısınız, sizin büyük imamınız Ahmed b. Hanbel, kamçı altında "Onun söylemediğini ben nasıl söylerim" sözünü söylüyordu. Onun mezhebinde olmayan bir şeyi mezheptenmiş gibi söylemekten yani bid'at çıarmaktan sizi sakındırırım!.. Aslın kendisiyle sabit olduğu akıl, asla ihmal edilemez. Çünkü biz onunla Allah'ı biliriz". ${ }^{58}$ Ehl-i Hadîsten bir âlimin geldiği bu nokta, aslında kelamcıların başından beri durduğu noktadır.

58 Ebü'l-Ferec İbnü'l-Cevzî, Def'u şubehi't-teşbîh, nşr. Ahmed Hicazî es-Sakka, Kahire 14121991, Mektebetü'1-Külliyâti'l-Ezheriyye, s. 8-9.

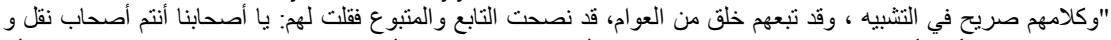

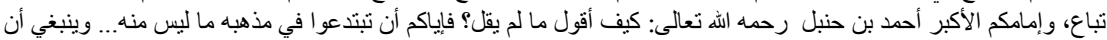

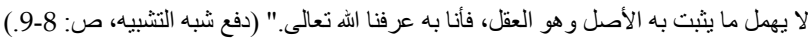

\begin{tabular}{|c|c|c|}
\hline Alâm Araștırmaları & $\begin{array}{l}\text { Kelâm Araştırmaları Dergisi } \\
\text { Journal of Kalâm Researches } \\
\text { [KADER-e-ISSN: 1309-2030] }\end{array}$ & $\begin{array}{cc}\text { C.: } 13, & \text { S.: } 2 \\
\text { V.: } 13, & \text { I.: } 2 \\
2015\end{array}$ \\
\hline
\end{tabular}




\section{Kaynakça}

Alaeddin el-Üsmendî, Lübâbü'l-Kelâm, nşr. Said Özervarlı, İstanbul 1495/2005, İsam.

Beyazîzâde Ahmed, İşârâtü'l-merâm, Kahire 1368/1949.

Cessas, Ahkâmü'l-Kur'ân, Beyrut 1424/2003, Daru'l-Kütübi'l-İlmiyye, I, 33; Ebü'l-Münteha, el-Külliyât.

Cürcânî, Şerhu'l-Mevâkıf, Kahire 1325/1907, el-Hac Muhammed Efendi.

Cüveynî, el-Giyâsî -Giyâsü'l-ümem fi'ltiyâsi'z-zulem-, nşr. Abdulhalim Dîb, Kahire 1401, Matbaatü Nahda.

Cüveynî, eş-Şâmil, nşr. Helmut Klopher, Kahire 1988-1989

Ebû Bekir İbnü'l-Arabî, Kanûnü't-te'vîl, nşr. Muhammed Süleyman, Beyrut 1990, Daru'1-Garbi'1-İslamî

Ebü'l-Berekât en-Nesefî, Şerhu Hafizüddîn en-Nesefî li Kitabi'l-Müntehab, nşr. Salim Öğüt, İstanbul ts.

Ebü'l-Ferec İbnü'l-Cevzî, Def'u şubehi't-teşbîh, nşr. Ahmed Hicazî es-Sakka, Kahire.

Ebü'l-Hasan el-Eş'arî, Makâlâtü̈l-İslamiyyîn, nşr. H. Ritter, Wiezbaden 1980.

Ebü'l-Leys es-Semerkandî, et-Tefsîr, Beyrut 1427/2006, Daru'l-Kütübi'lİlmiyye

Ebü'l-Muîn en-Nesefî, et-Temhîd fî usûli'd-dîn, nşr. Abdulhay kâbîl, Kahire 1407/1987, Daru's-Sekâfe.

Ebü'l-Münteha, el-Külliyât, Beyrut 1412/1992, Müessesetü'r-Risâle.

Ebü'l-Yüsr el-Bezdevî, Usulü'd-dîn, nşr. H.P. Linss, Kahire 1383/1963.

Ebü'n-Necîb es-Suhreverdî, Âdâbü'l-mürîdin, nşr. Nuceym Muhammed Şeltut, Kahire ts., Daru'l-Vatani'l-Arabî.

Fahreddîn er-Razî, et-Tefsîru'l-Kebîr (Mefâtîhu'l-gayb), Beyrut, Daru İhyau'tTurasi'l-Arabî.

Fahreddîn er-Râzî, Muhassalüll-efkâri'l-mutekaddimîn ve'l-müteahhirîn, nşr. Tahâ Abdurrauf Sa'd, Kahire, ts., Mektebetü'l-Külliyâti'l-Ezheriyye.

Gazzalî, "Fi'l-Akıl ve Şerefuh", Hâris el-Muhasibî, Şerefü'l-akıl ve mahiyyetühû, Beyrut 1406/1986, Daru'l-Kütübi'l-İlmiyye ile birlikte.

Gazzalî, el-ikktisâd fi'l-i't'ikâd, nşr. İ.A. Çubukçu-H. Atay, Ankara 1964, AÜïF. Yayınları.

Hâris el-Muhasibî, Şerefü'l-akıl ve mahiyyetühû, Beyrut 1406/1986, Daru'lKütübi'l-İlmiyye.

\begin{tabular}{|ccc|}
\hline Kelâm Araştırmaları Dergisi & C.: 13, & S.: 2 \\
\hline Journal of Kalâm Researches & V.: 13, & I.: 2 \\
[KADER-e-ISSN: 1309-2030] & 2015
\end{tabular}


İbn Fûrek, Mücerredü makâlâti'ş-Şeyh Ebi'l-Hasan el-Eş'arî, nşr. Daniel Gimaret, Beyrut 1987.

İbn Haldun, Şifaü's-sâil li tehzîbi'l-mesâil, nşr. Muhammed b. Tâvît et-Tancî, İstanbul 1958.

İmam Rabbânî, el-Mektûbât, Mekke 1317 $\rightarrow$ İstanbul ts., Fazilet Neşriyat.

Kadî Abdulcebbar, el-Muhtasar fì usûli'd-dîn, Muhammed Ammara, Resâilü'l-adl ve't-tevhîd, Kahire ts., Daru'l-Hilal.

Kadî Abdulcebbar, Şerhu'l-usûli'l-hamse, Kahire 1364/1965, Mektebetü Vehbe.

Kurtubî, el-Cami' li ahkâmi'l-Kur'ân, Kahire 1426/2005, Daru'1-Hadîs.

Matüridî, Te'vilâtü Ehli's-Sunne, nşr. Fatıma Yusuf el-Haymî, Beyrut , Müessesetü'l-Risâle.

Nâsıruddîn Ahmed, en-Necât, nşr. Seyyid Abdullah, Kahire 14021/2001.

Nureddin es-Sabunî, el-Kifâye, nşr. Muhammed Aruçi, İstanbul 1412/2011.

Sadüddîn et-Teftazânî, Şerhu'l-Akâid, nşr. Muhammed Adnan Derviş, yy. ts.

Sadüddîn et-Teftazânî, Şerhu'l-Mekâsıd, Beyrut 1409/1989, Alemü'l-Kütüb.

Sülemî, el-Mukaddime fi't-Tasavvuf, nşr. Yusuf Zeydan, Kahire 1407/1987, Mektebetü'1-Külliyeti'l-Ezheriyye

Şehristanî, Nihâyetü'l-İkdâm, Beyrut 1425/2004, Dâru'1-Kütübi'l-i̇lmiyye

Yusuf Şevki Yavuz, Kur'ân-ı Kerim'de Tefekkür ve Tartışma Metodu, Bursa 1983.

Zemahşerî, el-Keşşaf, Kahire ts., el-Mektebetü't-Tevfîkiyye.

\begin{tabular}{|c|c|c|}
\hline 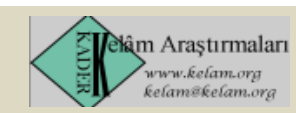 & $\begin{array}{l}\text { Kelâm Araştırmaları Dergisi } \\
\text { Journal of Kalâm Researches } \\
\text { [KADER-e-ISSN: 1309-2030] }\end{array}$ & $\begin{array}{cc}\text { C.: } 13, & \text { S.: } 2 \\
\text { V.: } 13, & \text { I.: } 2 \\
2015\end{array}$ \\
\hline
\end{tabular}

